\title{
Will you still need me, will you still feed me? Old-age pensions in Iceland from a gender perspective
}

\author{
Steinunn Rögnvaldsdóttir, MA in Gender Studies and Gyða Margrét \\ Pétursdóttir, adjunct in Gender Studies, University of Iceland
}

\begin{abstract}
Icelandic women have through the years earned less occupational and supplemental pensions and depended more than men do on the basic pension of social security. Although women's labour market participation has increased, the gender pay gap, unpaid labour in homes, and women's fewer working hours in paid labour results in the extension of the labour market gender discrimination into old age. The structure of Icelandic pension funds is fundamentally male biased because of its tight connection to employment, despite the absence of direct discrimination factors. The article provides an overview of implications for a more women friendly pension system; based on multi-national research; the analysis of the Icelandic pension system, and statistical information on older women and men's economic situation in Iceland. Adequate basic pension, elimination of labour market gender discrimination, and males taking greater responsibility for care- and housework, are some of the key issues in creating a more gender equal pension system. Sharing of pensions between spouses, the responsibility of pension-funds and companies, and possibilities of care credit systems to promote gender equality are also discussed.
\end{abstract}

Keywords: Pensions, gender, age, poverty, equality.

\section{Introduction}

In the aftermath of the economic crisis in Iceland in 2008, many pension funds were affected by a loss of assets which can be attributed to the funds' investment strategies. All funds lost assets due to the crisis and some funds ended up cutting the pension rights and payments to their members. In 2010, the Icelandic Pension Funds Association established a Review Committee to review the policy priorities, decisionmaking and risk evaluation in the investment strategies of the pension funds in the years before the crisis. The committee published an extensive report on the matter in February 2012. The report revealed that the pension funds had lost almost 500 billion ISK because of their investment strategies prior to the crisis. Board-members were criticized for neglecting their regulatory duties and for carelessness in certain 
investments. One of the main conclusions of the review was that the laws on pension funds should be revised (Bragason et al., 2012; RUV, 2012).

We would like to introduce another important factor into the public debate on the revision and improvements on the Icelandic pension system: the gender factor. Even though historically, both men's and women's labour market participation in Iceland is very high and unemployment rates low for both sexes, there are old women deriving pensions in the present who are greatly affected by historical structures and the gender discrimination of past decades still haunts them.

Housework and care for children and the elderly have through the years not been paid work. Consequently, women do not receive pensions based on this work. Although they are entitled to universal basic pension, it is a fact that this work, their contribution, is worthless when it comes to financial remuneration. Our article ${ }^{1}$ thus poses the question how women's unpaid work in past decades is affecting their economic security today in the context of pension payments, and how women's current situation in the labour market will affect their pensions in the future. In the article we emphasize society's gendered influence on the difference in men's and women's pensions and the gendered implications for improvement of the system. This is the first attempt to investigate the Icelandic pension system for the elderly from a gender perspective. Positioning the research from older women's standpoint has the potential to provide new critical questions about pension provisions in Iceland and how multiple factors such as age and gender can be at work simultaneously in creating and maintaining social inequality.

The research is based on quantitative data, i.e. statistical information on factors influencing men's and women's different economic position in old age. Statistical data was gathered from Eurostat, Statistics Iceland (Hagstofa Íslands), The Financial Supervisory Authority (Fjármálaeftirlitið) and the Social Insurance Administration (Tryggingastofnun). The data was analysed to highlight the gender variable in various factors affecting economic status and subsequently pensions, and how those factors collectively influence older women's economic situation. The results are discussed in the context of feminist theories which provide a useful frame for discussion of how inequality in society can be identified and eradicated.

\section{The structure of the Icelandic old-age pension system}

In general, pension systems are either pay-as you go systems (is. gegnumstreymiskerfi), where the pension system is funded by tax revenue, or funded systems (IS. sjóðsöfnun) where individuals pay part of their income in pension funds that invest the money until the time has come for individuals to retire. Both of these systems have their strengths and weaknesses. The main problem with funded systems is the danger of bad investments and loss of future pensioners' assets, as happened in the aftermath of the economic crisis in Iceland. The biggest problem facing systems with the pay-as-you-go system are rapid demographic changes. The system depends on equal numbers of individuals making up each generation, so 
that there are enough workers creating tax revenue for the pension system. Since birth rates have been declining in most Western countries, countries whose pension system is a pay-as-you-go system are facing difficulties financing their systems in the immediate future. Iceland still has one of the highest fertility rates among the Western countries, besides having an occupational pension system based on funding (Ólafsdóttir, 2011; Guðmundsson, 2004).

The Icelandic pension system rests on three pillars. The first is the pillar of the social security system, providing a safety net of guaranteed minimum income for all national citizens, financed with tax revenue and called a basic pension (is. grunnlifeyrir). The second pillar is the occupational pension system. The system is mandatory and funded (payments are based on funding and investment returns), in contrast to the common pay-as-you-go pension systems of many other OECD countries. The pension funds operating in Iceland are either occupational or independent funds, most of them private but publicly regulated. The third pillar is voluntary pension saving with tax incentives (is. viðbótarlífeyrissparnaður/ séreignarlífeyris-sparnaður). Contributions to pension systems are not taxed when they are made, resulting in larger amounts accumulating in the system through time. The pension is then taxed when it is paid out to the pensioners, in the same way as income from employment. Interest income of pensions is exempt from capital income tax (Icelandic Pension Funds Association, 2006). The Icelandic basic pension and social security system is related to the Scandinavian systems in the sense that the systems are structured around citizens' rights_-all nationals are guaranteed some basic rights as citizens.

\section{What factors shape a gender-equal pension system?}

A women-friendly pension system is firstly not structurally biased towards women, and secondly it must have its roots in a women-friendly environment. According to Vanja Ivoševic, a tight linking between contributions and benefits perpetuates the labour market inequalities, extending the gender pay gap to a gender pension gap. According to this, the very emphasis on occupational pension has been, and remains, women-unfriendly. Redistributive elements as minimum income guarantees and guaranteed old age pensions have been argued to be the most efficient tool to reduce gender difference in pensions (Ivoševic, 2009).

In pay-as-you-go systems (which are more common in Europe, while Iceland's three pillar system relies heavily on a funding system) the structure of an income base interval is important. An income base interval based on the best years, or end years, results in a lower gender bias than a career average base (average earnings over one's full career) due to women's career-breaks. Access to pension-schemes for part-time workers (the majority of whom are women) has also been an issue in the EU, and today the denial of such access constitutes indirect gender discrimination (Ivoševic, 2009). Other forms of access limitations are minimum retirement age (which has in many countries been lower for women), regular contribution requirements, minimum 
contribution periods, and minimum earning-thresholds - all of these access limitations can be found in various pension-schemes in Europe according to Ivoševic's research (2009). In a women-friendly pension system, such access limitations would be eliminated.

The use of gender-sensitive life-expectancy tables is also important. If pensions are calculated with regard to the estimated life expectancy of each gender, women would lose out because of their average longer life expectancies. A more womenfriendly option is not to take gender-difference into account and determine the pension regardless of differences in life expectancies. This method is used in the Icelandic pension system (Sigurgeirsdóttir, forthcoming). Other aspects that are important to take into account are the provisions for care credits and parental leave. Access for both parents to parental leave have to be secured, as must their pension rights through the period of care-giving. If not, the gender pension gap that already exists will be amplified further, as women have in the past, and still today, take the majority of parental leave. In Iceland, a premium is paid from parental leave benefits but people (most often women) in unpaid care-giving work have not had an independent right to pension benefits based on this work. General social security provisions have compensated for this.

Rights derived from family relations, if such rights are available, must not be gender biased but available to both men and women, for example survivor's benefits. Furthermore, the rights should be available regardless of the form of cohabitation, including same-sex partners. Such rights are based on the notion of dependency but even though there is an increasing trend in the proportion of women in the labour force, women still continue to be the primary care providers in their families, and the women deriving pensions now most certainly were in past decades. Therefore, provisions regulating derived pension rights from family relations are still of much relevance for older married or widowed women today (Ivoševic, 2009). However, provisions too tightly linking women's earnings to men's can also be a problem, such as means testing of earnings of a spouse. Such provision can undermine women's economic independence, which has been recognized in Iceland where such means testing was abolished in recent years.

A review of the Icelandic pension system with regard to possible gender discriminating aspects of the occupational pension system, leads us to the conclusion that the aspects of the occupational pension system are not gender discriminating per se. No onerous obligations for women appear in the system such as conditions of minimum contributions, length of periods of work or continuity, which is the case in some other countries. The life-expectancy tables used in Iceland are women-friendly as they are gender-sensitive and the different life expectancies of men and women do not affect the calculation of pensions. One could therefore say that women's situation within the occupational pension system is not the fault of the system; the fact is that women have through the years contributed less to the funds and therefore receive less pension amounts. Nevertheless, the foundations of the occupational pension systems rest on an employment market that is predicated upon ideas about a (male) provider. 
Will you still need me, will you still feed me?

Steinunn Rögnvaldsdóttir og Gyđa Margrét

Pétursdóttir

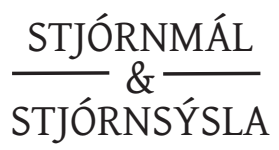

The occupational pension system has its origins in a gender discriminating society, which values and rewards labour market participation which has through the years been a primarily male arena, and which does not economically value women's work in homes and their care for children.

\section{Feminist theory}

This section provides useful theories for analysis of the gendered aspects of the Icelandic pension system. We use Connell's theory of the patriarchal state as a part of structural dominance, theories of the dilemma of dichotomy, free-riding and situation of unequal power in marriage, feminist economic citizenship and Nancy Fraser's universal caregiver model.

Patriarchy is a power constellation where women and males considered feminine as opposed to masculine, are oppressed by men and the culture of masculinity. The effects of a patriarchal society are visible in women's powerlessness, exemplified in political decision-making, earnings and so forth. The visibility of this male dominance varies in the aspects of everyday life (Holter, 1984), but is difficult to point to a person that directly exercises the power to oppress intentionally. R.W. Connell has stated that the patriarchal state is a part of structural dominance; patriarchy is thus embedded in the procedure of the state's functioning. Connell emphasizes that patriarchy is disguised as "neutrality"-but the truth is that it is heavily male-biased. Connell takes as an example "equal opportunity" or "pay equity" programmes that often call for a strictly objective assessment of jobs to overcome gender inequality in labour. This objective assessment can be contradictory if a patriarchal point of view is embedded in the underlying rationale of the evaluation (Connell, 1990). This is evident, for example, in the weighting of different aspects of a job, or in not valuing certain work, such as house and care work, as worthy of remuneration. Consequently the norm of objectivity becomes an institutionalization of men's interests.

Connell views the state as a central agent in the regulation of gender power relations. Gender dynamics are a driving force in the historical construction of the state, as in contemporary politics. The state has the institutionalized power to regulate gender relations in society, deciding who can marry whom, who labours and who cares for children and home, to mention a few scenarios. The state thus has the capacity to "do gender" and is not just a regulatory agency, but rather a creative (and possibly destructive) force in the dynamic of gender (Connell, 1990).

In paid work, women are excluded from the better forms of work and in a segregated work market they do the worse jobs which are deemed to be less skilled and inadequately paid. The relations of production of the household are patriarchal in nature, as the women's household labour is unpaid and expropriated by their husbands/cohabiters, according to Sylvia Walby (1990). This has been called "freeriding" by other scholars, such as Fraser (1994) and Pateman (2004), who have criticized how the term is mainly seen as a problem of people avoiding employment, 
but less consideration is given to the massive free-riding of men as husbands; freeriding on women's unpaid labour. It is notable to consider whether or not husbands are the only free-riders in this perspective, as society as a whole benefits from this unpaid care work, which otherwise would have to be paid for, probably by the state (which most often is responsible for care provisions such as day-care and care of sick and disabled people and the elderly).

Iris Marion Young suggests that men fail to take equal responsibility for housework and care in marriage, simply because they have the power not to, as they typically earn more than women. So although women spend many more unvalued working hours than their husbands taking care of the home and family, more often than not men are the primary decision makers in a household, because women depend on their husbands' income (Young, 1995). Gyða Margrét Pétursdóttir has suggested that this situation also manifests itself in men having greater leeway for leisure than women. Although men typically work longer hours in paid employment they make time for leisure and believe or perceive that they are doing their share of child care and housework. This is possible because of their power in relationships as the "breadwinner", since men on average earn more than women (Pétursdóttir, 2009).

Walby (1990) has pointed out that women-friendly provisions are in danger of having paradoxical effects because of patriarchy's adaptability. An example of this are care-benefits, which although meant to enhance women's economic freedom and independence, are not nearly adequate and make women dependent on the state. This creates the dichotomy between emphasis on women's labour work participation, and women's economic recognition for care work. This dichotomy has put its mark on women's emancipation worldwide. In Iceland we see this epitomized in the different ideologies of Rauðsokkahreyfingin and Kvennalistinn. If painted in broad strokes, the radical Rauðsokkahreyfing (Redstockings, active from 1970 to 1982), emphasized that women would achieve equality by obtaining the same societal status as men, i.e. gaining greater access to the labour market and politics. According to their ideology, women needed to be freed from their traditional roles as mothers and housewives. This is a different ideology from Kvennalistinn (the Women's Party, founded in 1983, active until 1998), which celebrated women's special cultural and social difference from men and emphasized that the contribution of women in all spheres of society would improve it (Jónsdóttir, S.V., 2006). The Women's party' advocated a more humanitarian economy and for the society to be governed as it was a home run by a practical housewife (Jónsdóttir, K., 2007).

This dichotomy has been named the "Wollstonecraft dilemma", after the feminist pioneer Mary Wollstonecraft (Pateman, 2004). The dilemma arises because of a pressure to choose to strive for equality either on the basis of equality or that of difference. To make the sexes equal is seen as making women equal to men and consequently making women more like men—males thus become the normative basis for citizenship and women remain constructed as the other. Emphasizing women's difference from men and consequently their special status in society, their activities, attributes and capacities, can be seen as enforcing stereotyping and notions about the 
"women's role" and other forms of essentialism (Pateman 2004, in Borchorst, 2009).

Both of these ideologies — striving for equal status and opportunities for the sexes and respecting women's special attributes and status — are important guiding lights on the way to gender equality. What has created trouble for feminist scholars is the claim that it is necessary to choose either difference or equality as the ideological ground we tread on our path to equality. Equality and difference have become regarded as logically incompatible (Borchorst, 2009). Most scholars agree, according to Borchorst, that the Wollstonecraft dilemma rests on a socially constructed dichotomy (Borchorst, 2009; Lister, 1997a). Many feminist scholars challenge this dilemma by pointing out the logical error that difference is not opposite to inequality, but to sameness. "The allegation that equality and difference are mutually incompatible is accordingly false, and has been constructed to curtail women's options" (Borchorst, 2009, 28). The answer to this dilemma is to unmask the power relationship constructed by posing equality as the antithesis of difference, and to reject the dichotomous construction of political choices. Equality does not mean that everyone is, or should be, identical, but rather we should consider obviously different people as equivalent (Scott, 1988).

The concept of citizenship provides a useful framework when researching women's status in society. The classical definition by T.H. Marshall goes: "Citizenship is a status bestowed on those who are full members of community. All who possess the status are equal with respect to the rights and duties with which the status is endowed" (Marshall, 1950, 28-29). Feminists such as Alice Kessler-Harris (in her article from 2003, In Pursuit of Economic Citizenship) and Ruth Lister have criticized the failure of traditional concepts of citizenships to address the gendered characteristics of economic rights and its strong bond with citizenship, for example how economic rights have excluded caregivers (Kessler-Harris in Melby, Ravn \& Wetterberg, 2009, Lister, 1997a and 1997b).

Ruth Lister emphasizes that citizen rights are social rights for all citizens in society, and those social rights help citizens to exercise civil and political rights-which are very important to disadvantaged groups and indispensable for the promotion of individual autonomy. Autonomy has a social dimension as well as an individual dimension, and the issue of autonomy is important to women in the light of their typical economic dependency, which can be seen as undermining their citizenship (Lister, 1997b). Lister argues that a feminist citizenship project would recognize women's agency and achievements as citizens, without losing sight of deep-rooted inequalities that still undermine many of the citizenship rights of women (particularly in the case of minority women). "Woman-friendly" citizenship thus combines the elements of gender-neutrality (same for men and women) and gender-difference approaches, while simultaneously remaining sensitive to the differences between women as a group (Lister, 1997a).

Equal and woman-friendly citizenship means abandoning the idea that those that are not self-sufficient are of lesser worth. Iris Marion Young argues that a "society that recognizes all its members as equal citizens and expects them all to make meaningful contributions must recognize and support the contribution of dependency 
work and publicly support many other opportunities for making social contributions“ (Young, 1995, 556). Adequate support for dependency workers, flexible working hours, guaranteed income, and other contributions recognizing care work would, in Young's estimation, probably result in men's greater participation in dependency work. An alternative of affordable care should also be available (Young, 1995). Rearticulating dichotomies and the rejection of the binary thinking that creates dichotomies, such as the Wollstonecraft dilemma, and the public-private divide, is an essential part of women-friendly citizenship. A caveat is in order though, so that women's citizenship is not simultaneously undermined-for instance, cash for care payments for those who choose to stay at home with children beyond the parental leave period - run the risk of weakening women's position in the labour market in the long term. Clearly, there is still a risk that policies that value difference might be implemented at the expense of equality (Lister, 1997a).

Scholar Nancy Fraser has described two current possibilities for the welfare state's support of gender equality in society. The current possibilities are the universal breadwinner model and the caregiver parity model, as Fraser describes it. In the universal breadwinner model, women take on the same role as male breadwinners, participating in paid labour while the public sector (or in some instances, the private sector) provides day-care for children (but care for children after day-care is still predominantly women's responsibility). The caregiver parity model, however, supports gender equality by acknowledging gender difference and supporting informal care in the family with caregiver allowances (Fraser, 1994). According to Fraser, both these possibilities have been tried out, and neither has resulted in gender equality. Neither model promotes women's full participation on par with men in politics and civil society, or values female work and practices enough to ask men to do them. In short, neither model asks men to change their ways to enhance equality. That is Fraser's third way: men changing and becoming more like women in practice and behaviour. A key to that is making women's combination of paid work and care and household work, the norm. Men must therefore increase their participation in care and household work (Fraser, 1994).

Fraser states that a change in that direction would create a welfare state based on the assumption that all employees also have caring duties. The shortening of the working week and institutions providing care would meet the demand, but it would not be expected that all care responsibility would be in the hands of institutions. Informal care work would be supported more adequately by the welfare state and have the same status as labour work within social insurance systems (Fraser, 1994). Fraser ends her article by saying: "This world is not likely to come into being in the immediate future. But it is the only imaginable post-industrial world that promises true gender equity, and unless we are guided by this vision now, we will never get any closer to achieving it" (Fraser, 1994, 613).

Fraser's universal caregiver model has been criticized for being utopian. Young's suggestion of economic reward for care as to enhance equal citizenship, could however affect its chances. But there is still the problem of paradoxical effects if such 
Will you still need me, will you still feed me?

a provision would backfire and bring women back into the home, without increasing men's participation in care, which could sustain men's free-riding on women's unpaid labour. The dichotomy of care work and labour market participation thus prevails.

\section{The gender dimensions of Icelandic society}

Various factors are at work in creating the gendered dimensions of society that in return influence old age pensions differently according to one's gender. Influential factors are for example fertility rate, life expectancy, disability, parental leave, domestic care roles, labour market participation and structure of the labour market - to name but a few. This section provides a brief statistical overview of these factors.

Life expectancy at birth was in 200980 years for Icelandic men and 83 years for Icelandic women (Ministry of Welfare, 2011a). Fertility rate (the total number of live births of a woman during her reproductive life) in Iceland has been between 1.9 and 2.3 in the last two decades (1990-2010), and it was approximately 2.2 in 2009 and 2010 (Statistics Iceland, 2012c). In 2009 it was the second highest among the OECD countries, only surpassed by Israel's (OECD Family Database, 2011). This fertility rate is high compared to most industrialized countries which do not reach the replacement fertility rate ${ }^{2}$ which is 2.1 - especially when viewed in the context of the high labour market participation of women in Iceland.

In 2012, people 65 years old and older made up $12.6 \%$ of total population of Iceland, with a bit more women than men, in accordance with their higher life expectancy rates (Statistics Iceland, 2012d). The number of people with disabilities has increased in the last decades. In 2010, women made up $61 \%$ of disability pensioners (9,025 women and 5,689 men). Among men 15.9\% aged 65-66 were disability pensioners in 2010, the corresponding number for women was $25.6 \%$ (Social Insurance Administration Iceland, 2011).

In $2010,86.8 \%$ of Icelandic men and $76.9 \%$ of Icelandic women were active in the labour market (Eurostat Statistics Database, 2012). In 2010, employment rates for Icelandic men were $43.8 \%$ and $26.6 \%$ for women 65 years or older, compared to $6.8 \%$ on average for males in EU-27 and 3.2\% of women in EU-27 for the same agegroup. This might be explained by the high official retirement age in Iceland (67 years), and high effective retirement age, along with other contributing factors such as a strong work ethic and incentives for delaying retirement (Ólafsson, 2010a). In March 2012, unemployment was 7.3\% among Icelandic men and 6.9\% among Icelandic women (Directorate of Labour, 2012). The unemployment rate has traditionally been extremely low in Iceland but increased in the wake of the economic crisis of 2008.

Women are more likely than men to work part-time. In 2010, 30.5\% of Icelandic women 25 years old and older had part-time jobs compared with 7.5\% of Icelandic men of the same age. Education seems to benefit men more than women in the labour market in terms of salary, even though women have for some time now been the majority of university students (Bjarnadóttir \& Árnadóttir, 2011). In her 
research from 2009 on Icelandic work culture, gender relations and family responsibility, Gyða Margrét Pétursdóttir demonstrated that gendered division of labour prevails in the different workplaces, bringing into light the gendered ideas of employers on parental roles, i.e. ideas of the father as a provider and the mother as a carer (Pétursdóttir, 2009).

The Icelandic labour market is heavily segregated, with women dominant in healthcare and education, and men dominant in industry, fishery, agriculture and management. Not only are wages lower in female dominated professions, women are also paid less on average within every sector of the labour market (from unspecialized workers jobs up to management). Consequently, women have on average lower income than men in Icelandic society (Ministry of Welfare, 2011a), as table 1 shows.

Table 1: Regular mean wages in the private sector by gender

\begin{tabular}{|c|c|c|c|c|c|c|}
\hline & \multicolumn{3}{|c|}{ Males } & \multicolumn{3}{|c|}{ Females } \\
\hline & 2000 & 2005 & 2011 & 2000 & 2005 & 2011 \\
\hline Wages in thousands ISK & 191 & 278 & 393 & 129 & 203 & 321 \\
\hline $\begin{array}{l}\text { Women's wages as a \% of } \\
\text { men's wages }\end{array}$ & & & & $68 \%$ & $73 \%$ & $82 \%$ \\
\hline
\end{tabular}

Source. Statistics Iceland 2012a

The gender pay gap (the difference in men's and women's wages) has been a great problem, as well as a contested issue. Research on the gender pay gap varies, but according to Statistics Iceland, full-time employed men in the private sector had on average total salaries of 503,000 ISK in 2011, while women had 400,000 ISK. That means men make over $25 \%$ more than women on average. In 2011, full-time working men worked on average 44.2 hours per week in paid labour, and women 41.6 hours (Statistics Iceland, 2012b). A comparison of wages among workers of different unions for the year 2011 shows an unexplained pay gap of $9.2 \%$ among Reykjavík's municipal employees' association, $13.2 \%$ within the union of public servants and $10.6 \%$ within VR (trade union of workers in the private sector in Reykjavík municipality) (SFR, 2011). Men also seem to receive more benefits at work, such as benefits for driving and more overtime work (Ministry of Welfare, 2011a).

Laws on parental leave from the year 2000 (maternity and paternity leave) provide parents with a total of 9 months of leave: 3 months for mother; 3 months for father, and 3 months to share (Lög um fæðingar- og foreldraorlof nr. 95/2000). Despite the relatively generous provisions for fathers, parental leave in Iceland is the shortest among the Nordic countries. Monthly payments to parents on parental leave are equal to $80 \%$ of parents' income up to 200,000 ISK, but $75 \%$ of parents' income above that level up to a ceiling of 300,000 ISK (Bjarnadóttir \& Árnadóttir, 
Will you still need me, will you still feed me?

Steinunn Rögnvaldsdóttir og Gyđa Margrét

Pétursdóttir

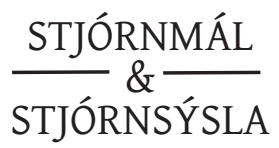

2011). The average number of days fathers take on parental leave was 103 in 2008 and 178 for women ${ }^{3}$ (Statistics Iceland, 2012e).

The period after birth leave can be troublesome for parents, since it is only 9 months, and children usually do not begin preschool until about two years of age. Until they do, parents have to rely on infant nurseries and day care, but such service is both expensive and plagued with long waiting lists. The right to unemployment benefits after birth leave for the parents is limited by the demand that they are actively seeking employment, which can be difficult when there is no option for the child's care other than by family members. This can lead to the loss of unemployment benefits and serious economic problems for the parents (Bjarnadóttir \& Árnadóttir, 2011).

Cash benefits for care of parents/family members is much less common in Iceland than in the other Nordic countries, as very few municipalities have homecare allowances ${ }^{4}$ and the cash grant is in all cases very modest (Rannsóknarstofa 1 barna- og fjölskylduvernd, 2010). Mothers were the vast majority of parents who received homecare allowances in 2009 in Reykjavík, which indicates that the mothers play a predominant role with regard to primary child care until other daycare possibilities are available. Although information is scarce on parents that leave the labour market and thus suffer loss of income because they must care for their children, it is estimated that women are the vast majority of those parents (Bjarnadóttir \& Árnadóttir, 2011). The lack of available day-care can therefore have serious consequences on mothers' employment status and economic independence.

Since 2005, men's hours spent doing housework have increased, and women's hours decreased. This suggests that the division of labour within households is becoming more equitable with regard to such duties. However, women still spend considerably more time than men doing housework; women on average spend 12.83 hours a week doing housework compared to men's 8.7 hours. Women also spend more time caring for children. Attitudes towards the division of housework indicate that a large proportion of men and women think that the division of housework is not fair, and both estimate that the woman's part accounts for the larger share. The group that spends most time on paid and unpaid work are married/cohabitating women with children, followed by single women with children, which suggests that the addition of a male in the home may actually increase the workload (Pórsdóttir \& Stefánsson, 2010).

\section{Pension statistics}

According to statistics, there is a considerable gender pay gap in Iceland which will affect pensions in the future. The pensions will also be affected by lower employment rates and higher part-time work rates for women, and a gender segregated labour market (discussed earlier in this article). Women's economic situations are already worse than men's. They have lower regular wages, there are substantial gender pay 
gaps in all occupational groups and women are more likely to be at risk of poverty as can be seen in table 2, the at-risk-of-poverty rate for women 75 years and older is $12.6 \%$, while it is $2 \%$ for males 75 years and older.

\section{Table 2: At-risk-of-poverty rate}

At-risk-of-poverty rate $(<65,65+, 75+)$ by sex, 2005/2009/2010. Per cent of total population (cut-off point: $60 \%$ of median equalised income after social transfers).

$$
\begin{array}{rrrrrrrrr}
<65 & \multicolumn{1}{c}{65+} & \multicolumn{3}{c}{75+} \\
2005 & 2009 & 2010 & 2005 & 2009 & 2010 & 2005 & 2009 & 2010
\end{array}
$$

\begin{tabular}{lccccccccc}
\hline & \multicolumn{10}{c}{ Iceland } \\
Males & 10 & 9.6 & 10.7 & 8.6 & 6.1 & 3 & 8 & 6.3 & 2 \\
Females & 9.6 & 10.1 & 10.2 & 9.8 & 17.9 & 6.6 & 14.4 & 26 & 12.6 \\
& & & \multicolumn{10}{c}{ EU-27 } \\
\hline & 15.7 & 15.9 & 19 & 15.5 & 14.9 & 16.9 & 16.2 & 12.9 & 14.4 \\
Males & 16.2 & 21.1 & 23.6 & 16.4 & 20.1 & 22.4 & 16.8 & 18.1 & 20.5
\end{tabular}

Source: Eurostat Statistics Database, 2012)

The economic situation of women in the labour market in the past decades is reflected in their much lower pension payments from occupational pension funds. Information on average pension payments by Icelandic occupational funds (from the Financial Supervisory Authority in Iceland) suggests that women's average pension is very often less than $50 \%$ of men's average pensions from the same occupational fund. In pension funds with more than a thousand members of each sex, women's ratio of men's pension ranges from being 31\% (Stafir lífeyrissjóður) to 69\% (Söfnunarsjóður liffeyrisréttinda). In the largest fund, the Pension fund of state-employees (Lífeyrissjóður starfsmanna ríkisins), women have on average $52 \%$ of men's average pension (The Financial Supervisory Authority, 2011). This shows clearly how the gender pay gap of past decades is extended into retirement.

Women make up a majority of recipients of the main types of benefits for old age pensioners from the Social Insurance Administration of Iceland (see table 3). Women are $58 \%$ of recipients, receiving approximately $59 \%$ of the expenditure. Women are $60 \%$ of those receiving pension supplements (tekjutrygging), and they receive about $63 \%$ of the expenditure. Women are $72 \%$ of those receiving household supplements (heimilisuppbót), and $68 \%$ of those receiving additional supplements (various supplements) and special pension supplements (lágmarks framfærslutrygging/sérstök uppbót til framfærslu), which is intended for individuals with very low incomes (table 3). In addition, women live on average longer than men and the scarce available data on women's exit from the labour market suggest women retire earlier than men. It is therefore clear that women have to live longer at a lower economic standard. 
Will you still need me, will you still feed me?

Steinunn Rögnvaldsdóttir og Gyđa Margrét

Pétursdóttir

STJÓRNSÝSLA

Table 3: Recipients of old age pension benefits and related social assistance 2010

Recipients in December $2010 \quad \begin{aligned} & \text { Expenditure } 2010 \text { in } \\ & \text { million ISK }\end{aligned}$

$\begin{array}{lllllll} & \text { Males } & \text { Fem. } & \text { Total } & \text { Males } & \text { Fem. } & \text { Total } \\ \text { Old age pension } & 10,455 & 14,658 & 25,113 & 3,311 & 4,723 & 8,034 \\ & 42 \% & 58 \% & & 41 \% & 59 \% & \\ \text { Pension supplement } & 8,719 & 12,909 & 21,628 & 5,065 & 8,569 & 13,634 \\ & 40 \% & 60 \% & & 37 \% & 63 \% & \\ \text { Spouse benefits } & 5 & 11 & 16 & 7 & 16 & 23 \\ \text { Home care payments } & -31 \% & 69 \% & & 30 \% & 70 \% & \\ \text { Household suppl. } & & 12 & 12 & 1 & 16 & 17 \\ & 2,052 & 5,199 & 7,251 & 391 & 1,000 & 1,391 \\ \text { Additional suppl. } & 28 \% & 72 \% & & 28 \% & 72 \% & \\ \text { Special pens.supp. } & 455 & 989 & 1,444 & 55 & 109 & 164 \\ & 32 \% & 68 \% & & 34 \% & 66 \% & \\ & 970 & 2,083 & 3,053 & 113 & 218 & 331 \\ & 32 \% & 68 \% & & 34 \% & 66 \% & \end{array}$

Source: Social Insurance Administration Iceland, 2011

In $201074 \%$ of the population, 67 years and older, received pensions from the Social Insurance Administration in Iceland. Unreduced basic pensions were received by $80 \%$ of the old age pensioners (Social Insurance Administration Iceland, 2011). The effects of the economic crisis in Iceland appear in pension statistics for example in lower capital income for pensioners. Capital income accounted for around 32.5\% of pensioners' income in 2007, but the share of capital income had gone down to approximately $23.5 \%$ in 2010 . The share of social security remained around $25 \%$ for both years, but the share of occupational pensions rose from $32.5 \%$ in 2007 to approximately 45\% in 2010 (Ólafsson in Sigurgeirsdóttir, forthcoming; Ólafsson, 2010b).

Also, due to losses of assets after the collapse, the occupational pension funds generally cut their pension rights and payments by about $10 \%$ in 2009 , and most of them repeated the action in 2010 (Ólafsson, 2010a). Since women receive less from occupational pension funds and depend more on social security, cuts of pensions in the occupational system has less effect on them as a group. In recent years, changes in the social security system have resulted in safeguarding the most vulnerable group of poor seniors, the majority of whom are women.(Ólafsson, 2010b; Ministry of Welfare, 2011b).

These statistics suggest that the gendered aspects of society, that is women's greater caring responsibility, their higher life expectancies and disability rates, and the segregation of the labour market and gender pay gap to employment, weaken women's 
attachment to wage work and consequently their accumulation of pension because of the close connection of pensions and employment history.

\section{Towards a more women friendly pension system}

As has been discussed, the Icelandic pension system is not gender equal, and we will therefore discuss a few implications of reforms for both Icelandic society and the Icelandic pension system, which would promote a more woman-friendly welfare society.

\subsection{Basic pension and income guarantee}

Many scholars have emphasized the importance of adequate basic pension levels for women who have accumulated small occupational pensions (Price, 2006; Ginn, 2003b; Jefferson 2009). The at-risk-of-poverty rate for women $65+(6.6 \%)$ and especially $75+$ $(12.6 \%)$ (table 2$)$ suggests that there are still a number of older women who have trouble making ends meet, and increasing the basic pension or the income guarantee in the Icelandic pension system would alleviate the danger of poverty for those women. This is also a seemingly gender-neutral operation, but with a gendered outcome since it would benefit more women than men. Alleviating poverty of older women with the use of the welfare system would constitute a part of a woman-friendly welfare society and compensate for the effects of a patriarchal society where women are discriminated against, as the labour market and wage discrimination discussed earlier are examples of. This action would be likely to promote gender equality but would mean extra expenditure from the state.

\subsection{Care-payments}

Care-payments are usually paid from the state to (female) carers. There are options of paying such benefits to women who in previous decades were responsible for household and child-care in the homes, or providing such payments while also paying people (more often women) in this situation today direct benefits for care of family members (children, elderly and disabled people ${ }^{5}$ ), of which they would pay a premium. There is also the option of granting acquired pension rights for care work-like for example in Norway (NAV, 2012). This can be associated with the cash-for-care benefits which have been common in neighbouring countries such as Norway and Finland, while this provision has very little roots or tradition in Iceland (Rannsóknarstofa í barna- og fjölskylduvernd, 2010).

The cash-for-care provisions are highly contestable. On the one hand the valuation of women's work in the home is a matter of justice, but on the other hand such provisions run the risk in the long run of weakening the situation of the carer who stays off the labour market. As earlier noted, these carers are predominantly women, and this may also affect their economic position if the benefits are modest (Rannsóknarstofa í barna- og fjölskylduvernd, 2010).

Here we face the danger of the pitfalls of dichotomy discussed earlier. Although words of caution are certainly in order when it comes to the gendered effects of 
cash-for-care, the cash-for-care provisions are not necessarily "a trap" for women, securing them in the homes for minimum pay. Even though the cash-for-care benefits in Iceland have historically been very modest (to put it mildly), there is not anything in the nature of the benefits that suggests that they should be so low. Higher cash-forcare benefits would serve to secure the economic citizenship of women (KesslerHarris in Melby, Ravn \& Wetterberg, 2009), and if the benefits were adequate, doing care work would appeal to more men according to Young (1995).

As discussed earlier, Nancy Fraser's theory (1994) of how we might reach gender equality rests on the prerequisite that men become more like women. Based on historical experience, that is not going to happen without providing motivation for men, and the economic factor is very important. Thus, an economic stimulus for care is maybe what is needed for men to become more like women. This was the spirit of laws on parental leave in Iceland when the "daddy" quota was implemented in 2000, to increase men's participation in the care of children by making sure that they would not receive a severe reduction in pay. When the law was implemented, parents received $80 \%$ of their salaries with no ceiling on payments (Einarsdóttir \& Pétursdóttir, 2009).

It must however be clear that from a feminist perspective a traditional cash-forcare payment system with modest benefits would not reach the goals discussed above: i.e. securing the economic citizenship of women; valuing care work, and appealing to men. Therefore, if implemented into the welfare system, cash-for-care benefits must be adequate or such an operation could pose a threat to gender equality. To sum it up, evidence is mixed that implementing care credits in the Icelandic welfare system would promote more gender equality. Adopting a care credit system would mean extra expenditure for the state.

\subsection{Eliminating the gender pay gap and labour market discrimination}

The gender pay gap and labour market discrimination are affecting women's pension accumulations today, and this will result in their average lower pensions compared to men in the future. Aspects of this discrimination are the gender segregated labour market and lower wages of occupational groups working in the public sector (VR, 2012), such as care-professions predominantly made up of women like teachers and nurses. Also, there is the unexplained gender pay gap (i.e. the average wage differential between men and women which is left unexplained when adjusted variables of difference have been accounted for), and the effects of women's heightened responsibility in the home, resulting in their shorter working hours. This is an example of the patriarchal aspects of society, resulting in discrimination against women. And every day this pattern persists is another day that women's future pensions continue to be lower than men's.

The elimination of labour market discrimination would balance the future pension payments. This is however obviously not as easy to do as reading or writing about it. Effort is needed, both on behalf of the state and the market. Here too we can lean on Fraser's theory (1994) of the universal caregiver, and emphasize that a change will 
probably never materialize unless men start behaving more like women. A change of attitude, tightened controls and heavier fines in the events of gender discrimination, better tools of measurements, and ultimately more gender equality in all spheres of society - as they are interconnected - are some of the key-instruments in creating a more gender-equal labour market and promoting gender equality in society.

\subsection{Occupational pension funds shouldering social responsibilities}

The responsibility of gender discrimination in the labour market is a vital matter for consideration. Who bears the responsibility is an important question for taxpayers who are affected by gender discrimination when elder women on pensions have to rely on state-pensions because of gender discriminating labour market of the past. If we leave out the gender segregated labour market, and even women's lower employment numbers of past and present, we still have the unexplained gender pay gap, which is a direct gender discrimination and a result of a patriarchal relations in society. The labour market and the state have a responsibility in stopping and correcting this discrimination.

Many boards of pension funds are made up of representatives of labour unions and employers. If occupational pension funds would shoulder their social responsibilities, one way to compensate for this discrimination would be to reduce it through pension benefits, for example with guaranteed minimum pension for all members, or women getting a "pension raise" equal to the average percentage of gender pay gap for a certain period, acknowledging that a part of the gap is a result of women working fewer hours because of their responsibilities at home. This is likely to meet resistance since contributions to pension funds are on an individual basis and it is a strong argument that fund members should not pay for discrimination of employers. It can be argued that financing of actions as these should rest on the employers of companies who have a history of gender wage gap, but there could be difficulties in revealing which companies have this history of discrimination. Measures in this spirit could also be implemented for the present, with more inspection of pay equality within companies and financial penalties in cases of discrimination. Action in this spirit would serve to make up for previous and present discrimination and in that way promote more gender equality.

\subsection{Sharing of pension between spouses}

In Iceland the sharing of pensions between spouses is possible. This is by no means an obligation. The sharing must be mutual; the couple must share the same percentage of each pension benefits, up to half of their acquired benefits. The sharing only applies to the acquired rights during the couple's marriage/registered partnership/cohabitation. An agreement can be made about a) sharing of pension after deriving of pension has already started, b) sharing of an already acquired pension and c) sharing of pension benefits that the couple will earn after the agreement has been made (Icelandic Pension Funds Association, 2006). This is a resource for couples where the division of work has been along the lines that one 
participates in the labour market and the other does care- and housework (most often the woman). In that way, the provision compensates for women's unpaid care and household work. Unfortunately there are no numbers available on how many couples use this resource ${ }^{6}$.

According to the $102^{\text {nd }}$ article of the Icelandic marriage laws (no. 31/1993), a spouse can demand that occupational and supplemental pension entitlements not be subjected to distributions of assets in the event of divorce. Other assets of the couple's income are subject to distribution between the separated couple. In the existing laws, there is a provision entailing that if it is deemed as unfair to the other spouse that pension entitlements are not a subject of distribution in the event of a divorce, it is possible for them to demand compensation. This provision was tried in the Supreme Court of Iceland in 2002, when a woman who had been a homeworker for 18 years in marriage, won a case which secured her financial payments of 2.5 million ISK from her ex-spouse (Fékk hlut í lífeyri eiginmanns við skilnað, 2002). Although this verdict created a precedent, it does not necessarily guarantee the equal distribution of the value of pension entitlements in the events of divorce, since the merits of cases vary, as well as the assessment of courts.

In 2010, there was a discussion in Norway on whether distribution of pensions should be made mandatory in the event of divorce, which was the suggestion of "Kvinnepanelen" or the Women's council, appointed by the Norwegian minister of equality. Further discussion even brought forward the views of those who considered whether pensions should be shared between couples regardless of events as divorce („Foreslår å frata men pensjon“, 2010). There also arose feminist criticism in Norway about the proposal, similar to the criticism of cash-for-care payments. Like the cashfor-care, this provision could result in supporting a society where women are dependent, whether on their husbands or the state, and men are considered providers while women are not encouraged to adapt to the rules of society and take control over their own lives (Bitsch, 2010). So although a just action, there are concerns that this will be mitigated by undesirable effects on women's independence.

Sharing of pensions between couples can be an acknowledgement and reward of women's contribution to the home. These are implications which the Icelandic legislators could consider, and which would not result in more expenditure for the state. However, it is unlikely that this provision will replace or completely compensate for full employment participation. Moreover, this is only an option available for cohabiting couples, and it does not affect the situation of single women. Furthermore, the current provision does not guarantee the equal sharing of pensions in the event of divorce if an agreement has not been made about the sharing of pension prior the divorce, as this provision is optional but not mandatory. It is therefore uncertain to what extent this measure can promote gender equality.

\section{Conclusions and discussion}

A general consensus is prevalent in public discussion that the upbringing of children and caring for the home is important work in society. In light of this it is 
fair to say that the state has profited from women's unpaid labour through the ages; it has in fact needed women. There is considerable danger, as can for example be seen in statistics on women's at-risk-of-poverty rate that this could result in women's poverty in old age. Therefore we refer to the Beatles classic song in the title, asking "will you still need me, will you still feed me" to draw attention to the state's and society's free-riding and consequent responsibility for women's economic security in old age.

In the wake of the economic crisis in Iceland, the actions of authorities to safeguard the most vulnerable groups have led to increases in old age pension benefits (Ministry of Welfare, 2011b). As shown in table 2 for the at-risk-of-poverty rate, the poverty risk was quite significant for old women in 2009 but now seems to have been markedly reduced. We conclude that this is probably the result of increase in benefits and subsequently relative better position of the most vulnerable and poor seniors. What this shows is the influence the state can have when it, as Connell puts it, is "doing gender" (Connell, 1990) - even if it is an unconscious step towards women's independence and equality, seeing how this step was not a specific action to promote gender equality but rather aimed towards solving a poverty problem.

The state is therefore in a key position when it comes to influencing the pension system, and the welfare system to become more women-friendly on the whole. The parental leave is an example here. The leave supports Fraser's universal caregiver model where men are encouraged to become more like women and take joint responsibility in care. The increase in fathers' uptake of parental leave since the daddy quota was implemented (Statistics Iceland, 2012e) suggests that Young is right in her emphasis on economic reward for care as a key instrument of equal economic citizenship of men and women. Fraser's way is also a gambit against the Wollstonecraft dilemma, which suggests women must strive for either equality or difference, because Fraser suggests that men must adopt the very thing that makes women different from men - the emphasis on caring - in the quest for achieving equality.

It is necessary to consider many perspectives to secure women's adequate pensions, both in the present and in the future. From this research we can conclude that the structure of the Icelandic occupational pension system seems not to be genderdiscriminating, as there seem to be no gender discrimination access limitations to the Icelandic pension system. The occupational pension system is, however, very closely linked to employment and the wages of members, and the emphasis on labour market participation in the whole Icelandic pension system has led to substantial gender difference in pensions. It will continue to do so while women's labour market earnings and participation continue to differ substantially from men's. In this research some suggestions to compensate for this have been outlined.

Based on the fact that the vast majority of seniors derive basic pensions from social security, and women derive less from occupational pension funds and more from social security, it can be concluded that adequate basic pensions, redistributive elements and securing the rights of women to pensions regardless of their employment history, are the most important factors in securing income security for women already 
deriving pensions. For women deriving their pension in the future, eliminating wage differences and other gender differences in the labour market and unequal distribution of work in the homes is imperative for the future of women's economic independence.

\section{Notes}

1 This article is based on the master's thesis of Steinunn Rögnvaldsdóttir, A haunted society: Old age pensions in Iceland from a gender perspective, from spring 2012. The thesis attempts to describe the influence of a gendered society on the difference in men's and women's pensions and the gendered implications for improvement of the pension system.

2 Replacement fertility rate is the total fertility rate required for population to maintain current population levels and replace it self in the long term, without migration.

3 Numbers for 2009/2010 are only preliminary since the right to take birth leave was spread over 36 months in July 2009, before that it was 18 months. At the present (14.10.2012), the latest update on statistical information available on the homepage of Statistics Iceland is from November 2011.

4 In 2009 this included 12 municipalities, and since then some of the municipalities have cancelled the homecare allowances, among others the municipal of the capital city Reykjavík.

5 It has also been suggested by disability researchers and people with disability that an even better arrangement would be to pay such fee directly to the one needing the care so that the person can hire and direct his or her own services.

6 According to the manager of the Icelandic Pension Funds Association (personal e-mail correspondence). March 13, 2012.

\section{References}

Aftenposten. (2010, August 25). „Foreslår å frata men pensjon“. Retrieved March 31, 2012, from Aftenposten Web site: http://www.aftenposten.no/nyheter/iriks/article3782571.ece

Bitsch, A. (2010, Oktober 9). „Anne Bitsch: Dagsavisen: Pensjonsparadokset“. Retrieved March 31, 2012, from Anne Bitsch: http://annebitsch.com/2010/09/09/pensjonsparadokset/

Bjarnadóttir, E., Arnardóttir, E. (2011). Konur i kreppu? Samantekt á opinberum tölulegum gögnum á ábrifum efnahagshrunsins á velfer đevenna. Reykjavík: Velferðarvaktin.

Borchorst, A. (2009). „,Woman-friendly policy paradoxes? Childcare policies and gender equality visions in Scandinavia“. In K. R. Melby, Gender equality and welfare politics in Scandinavia (pp. 27-42). Bristol: The Policy Press.

Bragason, H., Eyjólfsson, H. \& Frímannsson G.H. (2012). Úttekt á fjárfestingastefnu, ákvardanatöku og lagalegu umbverfi lifeyrissjódanna i aðdraganda bankabrunsins 2008. Reykjavík: Úttektarnefnd Landssamtaka lífeyrissjóða.

Connell, R. W. (1990). „The State, Gender and Sexual Politics: Theory and Appraisal“. Theory and Society, $19(5), 507-544$.

Directorate of Labor. (2012, February 14). Stada á vinnumarkadi Janúar 2012. Retrieved February 19, 2012, from Vinnumálastofnun:

http:/ / www.vinnumalastofnun.is/files/Sta $\% \mathrm{C} 3 \% \mathrm{~B} 0 \mathrm{a} \% 20 \% \mathrm{C} 3 \% \mathrm{~A} 1 \% 20$ vinnumarka $\% \mathrm{C} 3 \% \mathrm{~B} 0 \mathrm{i}$ $\% 20 j a n . \% 2012$.pdf

Einarsdóttir, P. \& Pétursdóttir, G.M. (2009). „Iceland: From reluctance to fast-track engineering“. In S. Kamerman; Moss, The Politics of Parental Leave Policies: Children, parenting, gender and the labor market (pp. 159-174). Bristol: The Policy Press.

Eurostat Statistics Database. (2012). Retrieved March 18, 2012, from http://epp.eurostat.ec.europa.eu/portal/page/portal/statistics/search_database

Fraser, N. (1994). „After the Family Wage: Gender Equality and the Welfare State“. Political Theory, 22(4), 591-618. 
Ginn, J. (2003b). „Pension and poverty traps: Is saving worthwhile for women?“. Journal of Financial Services and Marketing, 7(4), 319-329.

Guðmundsson, M. (2004). „The Icelandic pension system: Design and lessons for others“. Monetary bulletin, 6(1), 96-102.

Holter, H. (1984). „Women's Research and Social Theory“. In H. Holter, Patriarchy in a welfare society (pp. 9-25). Oslo: Universitetsforlaget.

Hjúskaparlög, nr. 31/1993. (14. April 1993). Reykjavík: Alpingi.

Icelandic Pension Funds Association. (May 2006). Liffeyrissjódurinn pinn - Lifou vel og lengi. Reykjavík: Landssamtök lífeyrissjóða.

Ivoševic, V. (2009). Pension reforms in Europe and their impact on women. Belgium: Education International.

Jefferson, T. (2009). „Women and Retirement Pensions: A Research Review“. Feminist Economics, 15(4), 115-145.

Jónsdóttir, K. (2007). "Hlustadu á pina innri rödd” Kvennaframbơ i Reykjavík og Kvennalisti 1982-1987. Reykjavík: Sögufélag.

Jónsdóttir, S. V. (2006, June 19). „Margt hefur nádst en enn er langt í jafnrétti“. Morgunbladið, pp. 1011.

Lister, R. (1997a). Citizenship: Feminist Perspectives. Basingstoke: Macmillan.

Lister, R. (1997b). „Citizenship: Towards a Feminist Synthesis“. Feminist Review, 57, $28-48$.

Lög um fæðingar- og foreldraorlof nr. 95/2000. (n.d.).

Marshall, T. (1950). Citizenship and Social Class. Cambridge: Cambridge University Press.

Melby, Ravn \& Wetterberg. (2009). „A Nordic model of gender equality? Introduction“. In K. R. Melby, Gender equality and welfare politics in Scandinavia: The limits of political ambition? (pp. 1-26). Bristol: The Policy Press.

Ministry of Welfare. (2011a). Jafnréttisping 2011: Skýrsla félags- og tryggingarmálarádherra um stödu og próun jafnréttismála og jafnrétti kynjanna i tölum. Reykjavík: Velferðarráðuneytið.

Ministry of Welfare. (2011b, 11 25). Lifeyrir og batur i velferdakerfinu bafa bakekad um átta milljarda i ár. Retrieved March 19, 2012, from http://www.velferdarraduneyti.is/frettir-vel/nr/33108

Morgunblaðið. (3. April 2002). „Fékk hlut í lífeyri eiginmanns við skilnað“. Morgunblaðið.

NAV. (2012). NAV: Aquired rights for care work. Retrieved March 31, 2012, from NAV website: http://www.nav.no/English/English/Omsorgsopptjening.805374461.cms

OECD Family Database. (2011, October 26). Retrieved February 17, 2012, from www.oecd.org: http://www.oecd.org/dataoecd/37/59/40192107.pdf

Ólafsdóttir, K. (2011). Viðanki II i Skýrslu úttektarnefndar Landssamtaka lifeyrissjóda. Reykjavík: Úttektarnefnd Landssamtaka lífeyrissjóða (2012).

Ólafsson, S. (2010a). Annual National Report Iceland 2010: Pensions, Health and Long-term Care. Iceland: European Commission, DG Employment, Social Affairs and Equal Opportunities.

Ólafsson, S. (2010b). Staða lífeyrispega í kreppunni. Reykjavík: Tryggingastofnun Íslands. Retrieved December 2nd, 2012, from

http://thjodmalastofnun.hi.is/sites/thjodmalastofnun.hi.is/files/skrar/stada_lifeyristega_i_krep punni.pdf

Pateman, C. (2004). „Democratizing Citizenship: Some Advantages of a Basic Income“. Politics \& Society, 32(1), 89-105.

Price, D. (2006). „Why are older women in the UK poor?“". Quality in Ageing and Older Adults, 7(2), 2332.

Rannsóknarstofa í barna- og fjölskylduvernd. (2010). Umönnun ungra barna i Reykjavík. Hluti II: Rannsókn RBF fyrir Leikskólasvið Reykjavikurborgar 2009-2010. Reykjavík: Rannsóknarstofnun í barna- og fjölskylduvernd.

RÚV. (2012, February 3). „Lífeyrissjóðirnir töpuðu 500 milljörðum“. Reykjavík. Retrieved October 14, 2012, from http://ruv.is/sarpurinn/frettir/03022012/lifeyrissjodirnir-topudu-500milljordum 
Scott, J. W. (1988). „Deconstructing Equality Versus Difference: Or the Uses of Poststructuralist Theory for Feminism“. Feminist Studies, 14(1), 33-50.

SFR. (2011). SFR: Launakönnun 2011: Samanburdur við önnur félög. Retrieved April 5, 2012, from SFR: Stéttarfélag í almannapjónustu: http://www.sfr.is/kannanir-sfr/launakonnun-sfr/launakonnun2011/samanburdur-vid-onnur-felog/

Sigurgeirsdóttir, S. (forthcoming). The socio-economic impact of pension systems on the respective situations of women and men and the effects of recent trends in pension reforms. National report Iceland. European Commission, Directorate of Justice.

Social Insurance Administration Iceland. (2011). Ársskýrsla og staðtölur Tryggingastofnunar 2010. Reykjavík: Tryggingastofnun.

Statistics Iceland. (2012a). Regular salaries in the private sector by occupational group and sex 1998-2011.

Retrieved April 12, 2012 from

http://www.statice.is/?PageID=1188\&src=/temp_en/Dialog/varval.asp?ma=VIN02015\%26ti $=$ Regular + salaries + in + the + private + sector + by + occupational + group + and + sex $+1998-$

$2011+++++++++\% 26$ path $=. . /$ Database $/$ vinnumarkadur $/$ fulllaun $/ \% 26$ lang $=1 \% 26$ units $=$ Tho usand $\% 20$ ISK

Statistics Iceland. (2012b). Earnings in the private sector 2011. Wages, income and labor market. Reykjavík: Hagstofa Íslands.

Statistics Iceland. (2012c). Fertility and reproduction rates 1853-2010. Retrieved February 17, 2012 from www.hagstofa.is:

http://www.statice.is/?PageID=1175\&src=/temp_en/Dialog/varval.asp?ma=MAN05202\%26ti $=$ Fertility + and + reproduction + rates $+1853-$

$2010++++++\% 26$ path $=. . /$ Database $/$ mannfjoldi $/$ faeddir $/ \% 26$ lang $=1 \% 26$ units $=$ pr $\% 201000 \%$

20women

Statistics Iceland. (2012d). Population by sex and age 1841-2012. Retrieved March 18, 2012 from

http://www.statice.is/?PageID=1170\&src=/temp_en/Dialog/varval.asp?ma=MAN00101\%26ti

$=$ Population + by + sex + and + age +1841 -

$2012++\% 26$ path $=. . /$ Database $/$ mannfjoldi $/$ Y firlit $/ \% 26$ lang $=1 \% 26$ units $=$ Number

Statistics Iceland. (2012e). Average length of maternity/paternity leave per parent by birthyear of child 2001 -

2010. Retrieved April 12, 2012 from

http:/ /www.statice.is/?PageID=1286\&src=/temp_en/Dialog/varval.asp?ma $=$ HEI03110\%26ti

$=$ Average + length + of + maternity $\% 2$ Fpaternity + leave + per + parent + by + birthyear + of + child +200 $1-2010++++\% 26$ path $=. . /$ Database $/$ heilbrigdismal $/$ tryggingar $/ \% 26$ lang $=1 \% 26$ units $=$ Number

The Financial Supervisory Authority. (2011). Lifeyrissjödir: Arsreikningar 2010 ásamt kennitölum og ödrum upplýsingum. Reykjavík: Fjármálaeftirlitið.

VR. (2012). VR \& SFR \& STRV. Retrieved October 13, 2012, from http://www.vr.is/kannanir/launakonnun-2012/vr-sfr-strv/

Walby, S. (1990). Theorizing patriarchy. Oxford: Blackwell.

Young, I. M. (1995). „Mothers, Citizenship and Independence: A Critique of Pure Family Values“. Ethics, 105(3), 535-556.

Pórsdóttir, P. K., Stefánsson, K. (2010). „Verkaskipting kynjanna fyrir og eftir bankahrun“. Fréttabréf Djódmálastofnunar Háskóla Íslands(10), pp. 1-5. 
